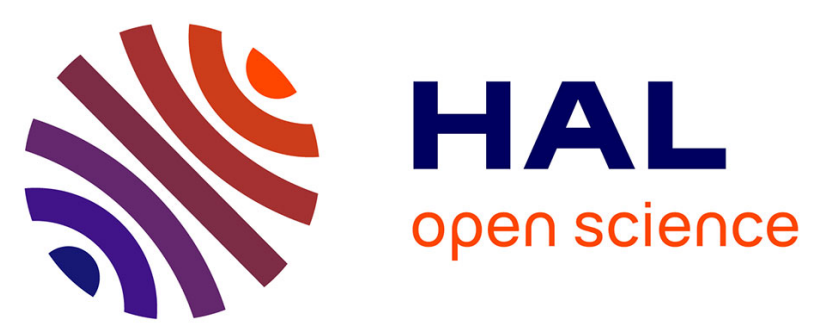

\title{
Tuning the Electronic Properties of Nonplanar exTTF-Based Push-Pull Chromophores by Aryl Substitution
}

Raúl García, M Ángeles Herranz, M Rosario Torres, Pierre-Antoine Bouit, Juan Luis Delgado, Joaquín Calbo, Pedro M. Viruela, Enrique Ortí, Nazario

\author{
Martín
}

\section{To cite this version:}

Raúl García, M Ángeles Herranz, M Rosario Torres, Pierre-Antoine Bouit, Juan Luis Delgado, et al.. Tuning the Electronic Properties of Nonplanar exTTF-Based Push-Pull Chromophores by Aryl Substitution. Journal of Organic Chemistry, 2012, 77 (23), pp.10707 - 10717. 10.1021/jo302047m . hal-01443308

\section{HAL Id: hal-01443308 https://hal.science/hal-01443308}

Submitted on 17 Jul 2020

HAL is a multi-disciplinary open access archive for the deposit and dissemination of scientific research documents, whether they are published or not. The documents may come from teaching and research institutions in France or abroad, or from public or private research centers.
L'archive ouverte pluridisciplinaire HAL, est destinée au dépôt et à la diffusion de documents scientifiques de niveau recherche, publiés ou non, émanant des établissements d'enseignement et de recherche français ou étrangers, des laboratoires publics ou privés. 


\title{
Tuning the Electronic Properties of Nonplanar exTTF-Based Push-Pull Chromophores by Aryl Substitution
}

\author{
Rául García, ${ }^{[a]} M^{a}$ Ángeles Herranz, ${ }^{[a]} M^{\mathrm{a}}$ Rosario Torres, ${ }^{[\mathrm{a}]}$ Pierre-Antoine Bouit, ${ }^{[\mathrm{b}]}$ Juan Luis \\ Delgado, ${ }^{[b]}$ Joaquín Calbo, ${ }^{[c]}$ Pedro M. Viruela, ${ }^{[c]}$ Enrique Ortí, $*[c]$ and Nazario Martín, ${ }^{*[a, b]}$
}

\begin{abstract}
A new family of $\pi$-extended tetrathiafulvalene (exTTF) donor-acceptorchromophores has been synthesized by [2 +2$]$ cycloaddition of TCNE with exTTF-substituted alkynes and subsequent cycloreversion. X-ray data and theoretical calculations,performed at the B3LYP/6-31G**level, show that the new chromophores exhibit highlydistorted nonplanar molecular structures with largely twisted 1,1,4,4-tetracyanobuta-1,3-diene (TCBD) units. The electronic and optical properties, investigated by UV/visspectroscopy and electrochemical measurements, are significantly modified when theTCBD acceptor unit is substituted with a donor phenyl group, which increases the twistingof the TCBD units and reduces the conjugation between the two dicyanovinyl subunits. The introduction of phenyl substituents hampers the oxidation and reduction processesand, at the same time, largely increases the optical band gap. An effective electroniccommunication between the donor and acceptor units, although limited by the distortedmolecular geometry, is evidenced both in the ground and in the excited electronic states. The electronic absorption spectra are characterized by low- to medium-intense charge-transfer bands that extend to the near-infrared.
\end{abstract}

\section{Introduction}

The design and synthesis of novel charge-transfer (CT) chromophores is currently a very active research area for a number of technological applications, particularly in fields such as nonlinear optics ${ }^{[1]}$ and organic photovoltaics. ${ }^{[2]}$ In this context, the structure of a molecular electron-donor is modified by the introduction of electron-acceptor groups, which create an internal CT. A large variety of donor materials, specially oligothiophenes or triphenylamines, have been combined with different electron-acceptor moieties. ${ }^{[3]}$ However, a limited number of non-planar donor-acceptor chromophores have

R. García, Dr. M. A. Herranz, Prof. Dr. N. Martín

Departamento de Química Orgánica

Facultad de Ciencias Químicas, Universidad Complutense

Ciudad Universitaria, 28040 Madrid (Spain)

Fax: (+34) 91-394-4103

E-mail: nazmar@quim.ucm.es

Dr. P.-A. Bouit, Dr. J. L Delgado, Prof. Dr. N. Martín

IMDEA-Nanociencia, Facultad de Ciencias

Universidad Autónoma, Cantoblanco, 28049 Madrid (Spain)

[c]

Prof. Dr. E. Ortí

Instituto de Ciencia Molecular, Universidad de Valencia 46980 Paterna (Spain)

Fax: (+34) 96-354-3274

E-mail: enrique.orti@uv.es

Supporting information for this article is available on the WWW under http://www.chemeurj.org/ or from the author. been reported, ${ }^{[4]}$ and only recently the relationship existing between $\pi$-conjugation and the electronic properties in these push-pull molecules have systematically been investigated. ${ }^{[5]}$

Diederich and co-workers showed that alkynes substituted with suitable electron-donating groups readily undergo a $[2+2]$ cycloaddition with tetracyanoethylene $(\mathrm{TCNE})^{[6]}$ and $7,7,8,8-$ tetracyanoquinodimethane (TCNQ), ${ }^{[6,7]}$ followed by a retroelectrocyclization to give CT chromophores such as the ones depicted in Figure 1. This general process, besides fulfilling all the requirements for a "click reaction" (atom economy, high yields, ambient conditions), provides easy access to functional materials, which in principle could feature enhanced physical properties when compared with their planar analogues such as better solubility, dispersability or sublimation capability, which are desirable for the preparation and processing of different optoelectronic devices. ${ }^{[8]}$ 

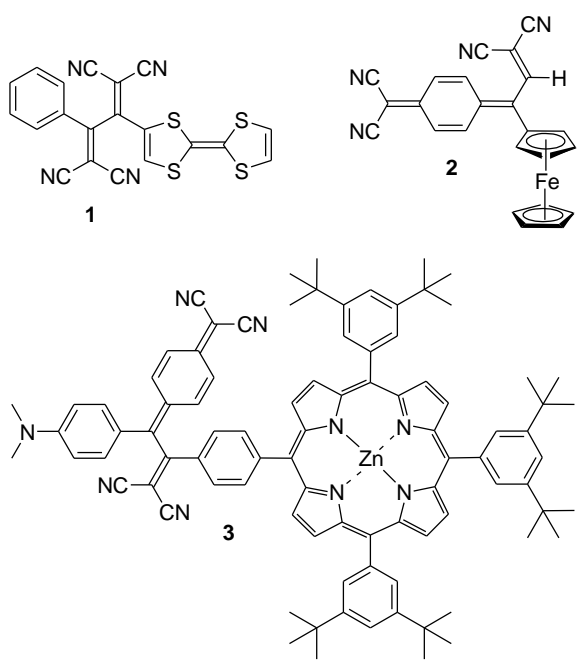

Figure 1. Representative examples of push-pull chromophores synthesized by cycloadditionretro-electrocyclization processes between donor-activated alkynes and TCNE and TCNQ.

With regards to electron-donors, $\pi$-extended tetrathiafulvalenes (exTTFs) have been widely used in the preparation of photo- and electroactive donor-acceptor dyads and triads, ${ }^{[9]}$ molecular wires, ${ }^{[10]}$ materials for second- and third-order nonlinear optics, ${ }^{[1]}$ as a building block in supramolecular chemistry, ${ }^{[12]}$ and more recently, for the realization of dye-sensitized solar cells. ${ }^{[13]}$ In addition, exTTFs are proaromatic units, ${ }^{[14]}$ with a characteristic butterfly shape distorted geometry, ${ }^{[15]}$ that upon oxidation experience a dramatic geometrical change resulting in a gain of aromaticity and planarity. Thus, the exTTF fragment looks particularly promising for modulating the conjugation and optimizing the electronic properties of push-pull chromophores.

In this work, we focus our attention on a new family of D- $\pi$-A in which exTTF and 1,1,4,4-tetracyanobuta-1,3-diene (TCBD) are covalently connected by considering the electronically controlled $[2+2]$ cycloaddition of TCNE with exTTF-substituted acetylenes, followed by retro-electrocyclization of the initially formed cyclobutenes (Schemes 1 and 2). The detailed electrochemical and optical characterization of compounds 7,8 and 12 reveal the important effect that the substituents on the exTTF core have on the structure and optical properties of these chromophores. Theoretical density functional (DFT) calculations have been carried out to gain additional insight into the electronic properties of these novel nonplanar push-pull chromophores.

\section{Results and Discussion}

Synthesis and Characterization. The synthesis of the push-pull chromophores 7 and 8 (Scheme 1) started with a Sonogashira coupling reaction of 2-iodo-9,10-bis(1,3-dithiol-2-ylidene)-9,10dihydroanthracene (4) ${ }^{[16]}$ with ethynyl(trimethyl)silane (to obtain compound 5 ${ }^{[17]}$ or phenylacetylene (for the synthesis of $\mathbf{6}$ ) in the presence of tetrakis(triphenyl-phosphine)palladium $(0)\left(\mathrm{Pd}\left(\mathrm{PPh}_{3}\right)_{4}\right)$, copper iodide and diisopropylamine or triethylamine, followed by desilylation with $\mathrm{K}_{2} \mathrm{CO}_{3}$ for the case of compound $\mathbf{5}$. exTTFs $5^{[17]}$ and 6 were obtained with a good overall yield (60-70\%). The subsequent reaction of these exTTF-based alkynes with TCNE led to the target molecules with moderate yields (35-70\%) after purification by column chromatography. Initial efforts to convert alkyne 6 to TCBDexTTF 8 in refluxing benzene were unsuccessful. The reaction proceeds however, when 1,2-dichloroethane was used as solvent, despite the starting alkyne $\mathbf{6}$ is sterically hindered compared to $\mathbf{5}$ resulting in different obtained yields ( $70 \%$ for $\mathbf{7}$ and $35 \%$ for $\mathbf{8}$ ).

Scheme 2 outlines the synthesis of $\mathbf{1 2}$ in which the initial Sonogashira coupling reaction of $\mathbf{9}$ with phenylacetylene in the presence of $\mathrm{Pd}\left(\mathrm{PPh}_{3}\right)_{4}, \mathrm{CuI}$ and triethylamine, afforded exTTF 10 in a good overall yield $(65 \%)$. When derivative 10, which bears two acetylenic moieties, was treated with a large excess $(c a .10 \mathrm{mmol})$ of TCNE, the expected bisadduct was formed, but the reaction did not proceed to completion. Monoadduct $\mathbf{1 1}$ was obtained from the reaction, and the subsequent deactivation of the second alkyne unit makes the second addition very slow. ${ }^{[18]}$ The doubly functionalized derivative $\mathbf{1 2}$ was only isolated in $35 \%$ yield after 5 days of reaction.

The synthesized TCBD-exTTF derivatives are coloured and stable solids that can be stored for months in the laboratory withouth decomposition. They are also readily soluble in common organic solvents due to their non-planar structure that might reduce chromophore aggregation. The structural assignment of compounds is based on analytical and spectroscopic techniques (i.e., UV-vis, FTIR, ${ }^{1} \mathrm{H}$ NMR, ${ }^{13} \mathrm{C}$ NMR and HRMS). In particular, compounds 7 , $\mathbf{8}, \mathbf{1 1}$ and $\mathbf{1 2}$, show the presence of a strong cyano stretching vibration at $\sim 2200 \mathrm{~cm}^{-1}$ in the FTIR spectrum. ${ }^{1} \mathrm{H}$ and ${ }^{13} \mathrm{C}$ NMR spectra showed the expected signals that correspond to both exTTF and TCBD moieties: the signals of the two 1,3-dithiole rings in the region of $\delta$ 6.6-6.3 of the ${ }^{1} \mathrm{H}$ NMR and, the $s p$ carbon atoms of the cyano groups at $\delta 114-110$ in the ${ }^{13} \mathrm{C}$ NMR. For additional details see the experimental and supporting information (SI) sections.

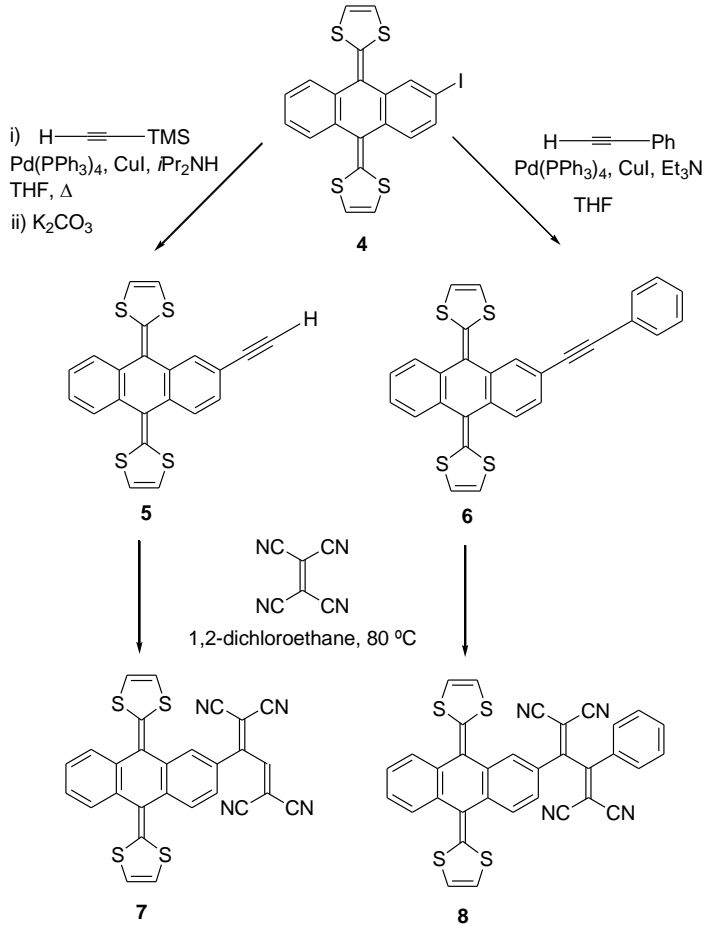

Scheme 1. Synthesis of TCBD-exTTF derivatives $\mathbf{7}$ and $\mathbf{8}$. 


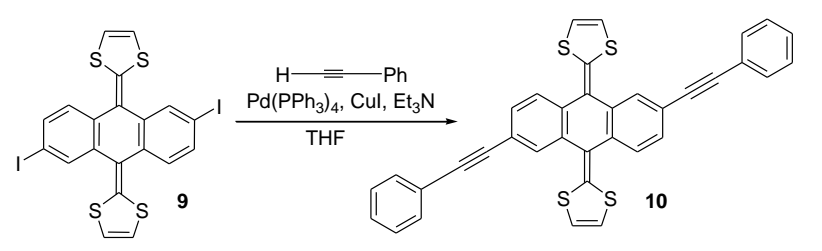<smiles>N#CC(C#N)=C(C(C#N)=C(C#N)c1ccccc1)C(=C(C#N)C#N)c1ccccc1</smiles><smiles>N#CC([18OH])=C(C#N)C#N</smiles>

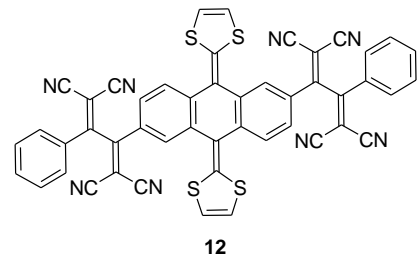

Scheme 2. Formation of the doubly TCBD functionalized exTTF derivative $\mathbf{1 2}$ by Sonogashira coupling followed by a [2+2] cycloaddition-cycloreversion reaction with TCNE.

Molecular structure. Crystals of $\mathbf{1 2}$ suitable for crystallographic analysis were grown by slow evaporation of a cooled hexane/ $\mathrm{CH}_{2} \mathrm{Cl}_{2}$ $1 / 1$ solution. The molecular structure of $\mathbf{1 2}$, a mixed solvate with a molecule of $\mathrm{CH}_{2} \mathrm{Cl}_{2}$ (Figure 2), arranges in a packing motif of pseudodimers of molecules with mutually recognizing bis(dithiole) anthraquinone moieties. Considerable non-planarity is observed in all the molecule and in particular for the TCBD and exTTF moieties (see Table $\mathrm{S} 1$ for crystallographic parameters). Thus, the dihedral angle $\theta$ (C9-C11-C12-C13) between the two dicyanovinyl planes is $-76.2^{\circ}$, which compares with similar $\pi$-deconjugated systems previously reported. ${ }^{[5]}$

In addition, the central ring of the anthracene unit folds in a boat conformation and the molecule adopts a saddle-like structure, in which the benzene rings point upwards and the dithiole rings point downwards. The conformation of the exTTF moiety is also consistent with the crystal structures observed for different derivatives. ${ }^{[19]}$ In this geometry, all four cyano groups converge into one hemisphere, whereas the exTTF donor moiety point into the other. The reaction mechanism provides de s-cis conformer after the thermal opening of the cyclobutene reaction intermediate and due to the sterical hindrance between the donor and acceptor units the structure does not evolve to the most stable s-trans conformation.

The experimentally observed bond lengths of $\mathbf{1 2}$ are of the expected order of magnitude for $\mathrm{CC}$ bonds in conjugated or aromatic structure $(1.40 \pm 0.08 \AA)$, C-S bonds $(1.73 \pm 0.03 \AA)$ or $\mathrm{C} \equiv \mathrm{N}$ $(1.13 \pm 0.01 \AA)$ bonds. The shortest bond lengths correspond to the CC bonds of the dithiole rings (1.29 $\AA$ ) and to the exocyclic CC bonds linking the dithiole rings to the anthracene units $(1.36 \AA)$.

Unfortunately, we were unable to produce single crystals of $\mathbf{7}$ and $\mathbf{8}$. However, comparison between the crystal structure of $\mathbf{1 2}$ and the optimized geometries of compounds 7, 8 and $\mathbf{1 2}$ computed at the B3LYP/6-31G** level confirm that calculations are very helpful in predicting the chemical structure of these molecules.

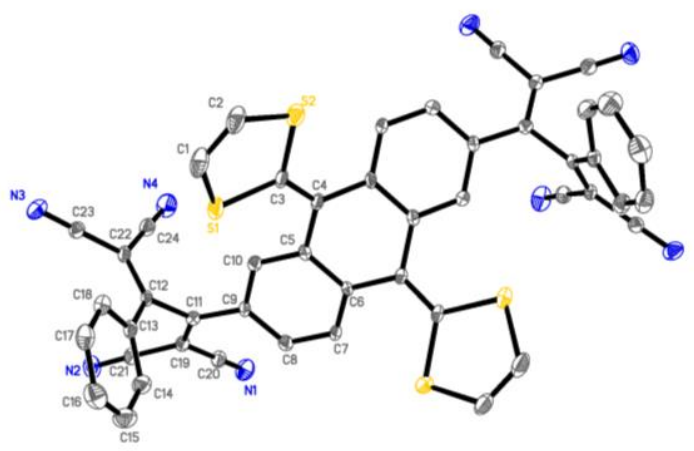

Figure 2. ORTEP representation of the molecular structure of $\mathbf{1 2}$.

From the intensive conformational study we conclude that the scis conformer is a local minimum (only $2 \mathrm{kcal} / \mathrm{mol}$ more energetic than the most stable s-trans conformer) and it is the most reasonable structure due to the mechanism that takes places in the synthesis.

As expected, the exTTF moiety has the typical saddle-like shape in all three compounds (Figure 3). ${ }^{[20]}$ Acceptor moieties are not coplanar with the aromatic ring of the anthracene unit to which are attached due to steric hindrance. The two halves of the acceptor moiety are facing upwards to the plane generated by the part of the anthracene to TCBD unit is attached. The phenyl group is therefore oriented downwards in $\mathbf{8}$.
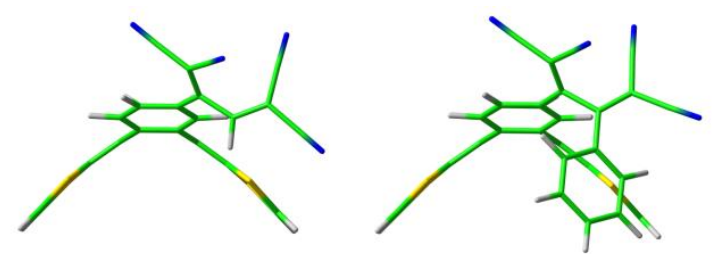

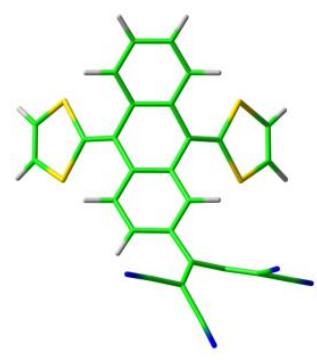

7

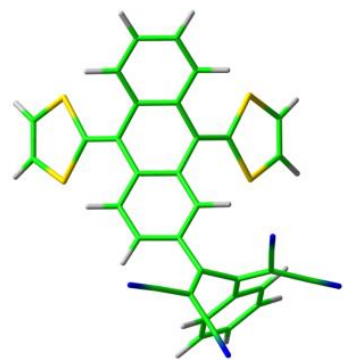

8
Figure 3. Minimum-energy B3LYP/6-31G** structure of 7 and 8

Electrochemical properties. Cyclic voltammetry (CV) and differential pulse voltammetry (DPV, see SI) experiments have been carried out with 7, 8 and 12 and compared to reference exTTF and TCNE compounds. In Table 1 the redox potentials are summarized, while Figure 4 displays the cyclic voltammograms in THF. 
Table 1. Cyclic voltammetry (CV) data for $\mathbf{7 , 8}$ and $\mathbf{1 2}$ and reference exTTT ${ }^{[a]}$ and TCNE derivatives in THF $\left(+0.1 \mathrm{M} \mathrm{TBAPF}_{6}\right) .{ }^{[\mathrm{b}]}$ Summary of electrochemical and optical energy gaps.

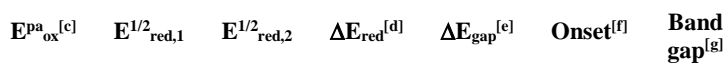

\begin{tabular}{cccccccc}
\hline exTTF & +244 & - & - & - & - & - & - \\
TCNE & - & -24 & -1112 & - & - & - & - \\
$\mathbf{7}$ & +307 & -348 & -1094 & 746 & 0.65 & 1322 & 0.93 \\
$\mathbf{8}$ & +346 & -540 & -940 & 400 & 0.87 & 929 & 1.33 \\
$\mathbf{1 2}$ & +419 & -524 & -981 & 457 & 0.94 & 925 & 1.34 \\
\hline
\end{tabular}

[a] Reference exTTF = 2-[9-(1,3-dithiol-2-ylidene)anthracen-10(9H)-yilidene]-1,3dithiole. [b] Potentials in $\mathrm{mV}$ versus $\mathrm{Ag} / \mathrm{AgNO}_{3}$. Working electrode: glassy carbon electrode; counter electrode: $\mathrm{Pt}$; reference electrode: $\mathrm{Ag} / \mathrm{AgNO}_{3}$. Scan rate: $0.1 \mathrm{~V} \mathrm{~s}^{-1}$. $\mathrm{E}^{1 / 2}=\left(\mathrm{E}^{\mathrm{pa}}+\mathrm{E}^{\mathrm{pc}}\right) / 2$, where $\mathrm{E}^{\mathrm{pc}}$ and $\mathrm{E}^{\mathrm{pa}}=$ cathodic and anodic peak potentials, respectively. [c] Anodic peak potential. [d] $\Delta \mathrm{E}_{\text {red }}=\mathrm{E}^{1 / 2}$ red,1 $-\mathrm{E}^{1 / 2}$ red, 2 in $\mathrm{mV}$. [e] $\Delta \mathrm{E}_{\text {gap }}=\mathrm{E}^{\mathrm{pa}}{ }_{\text {ox }}-\mathrm{E}^{1 / 2}$ red,1 in $\mathrm{V}$. [f] Absorption onsets in $\mathrm{nm}$. [g] Optical band-gaps in eV.

The exTTF-TCBD derivatives $\mathbf{7}, \mathbf{8}$ and $\mathbf{1 2}$ exhibit the characteristic $2 \mathrm{e}^{-}$quasi-reversible oxidation of exTTF ${ }^{[21]}$ at gradually increasing positively shifted potentials $(+307 \mathrm{mV}$ for $7,+346 \mathrm{mV}$ for 8 and $+419 \mathrm{mV}$ for 12) and, in all cases, at higher potential values than the reference exTTF compound $(+244 \mathrm{mV})$. The oxidation seems to be more difficult by the conjugation with the strong tetracyanobutadiene acceptor and, in the case of derivatives $\mathbf{8}$ and $\mathbf{1 2}$, due to the distorted geometry induced by the phenyl substitution.

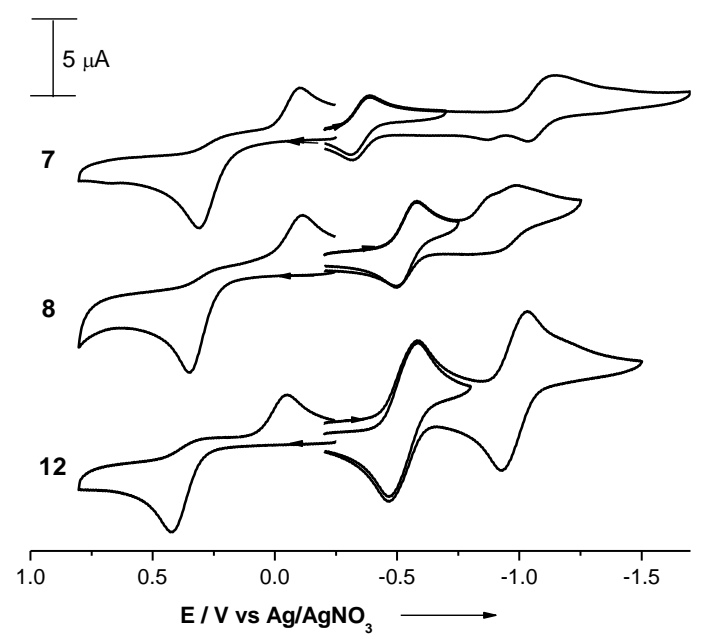

Figure 4. CVs of compounds 7, 8 and $\mathbf{1 2}$ in THF, $0.1 \mathrm{M} \mathrm{TBAPF}_{6}$, with a scan rate of 0.1 $\mathrm{V} / \mathrm{s}$

The cyclic voltammograms of compounds $\mathbf{7}$ and $\mathbf{8}$ feature two well-resolved reversible reduction couples with similar currents for each peak (1 $\mathrm{e}^{-}$each) centered on the tetracyanobutadiene acceptors. In the case of compound $\mathbf{1 2}$ the peak current increases significantly due to the presence of two acceptor units (each reduction step corresponds to $2 \mathrm{e}^{-}$). The cathodic shifts observed in the first reduction potential originate from $\pi$-conjugation of the acceptor to the exTTF unit. The reduction processes are also strongly influenced by the introduction of substituents $(\mathrm{Ph} v s \mathrm{H})$ that increase the molecular distortion from planarity and induce a clear loss of conjugation between the two acceptor halves of the TCBD unit. This effect is also visible in the second reduction potentials. A larger difference between the first and second reduction potentials $(746 \mathrm{mV})$ is observed in the exTTF-TCNE derivative 7, in which the two TCBD units are more efficiently $\pi$-conjugated. In contrast, substitution seems to induce a larger twist between the two acceptor subunits in $\mathbf{8}$ and 12, and first and second reduction potentials become closer $\left(\Delta \mathrm{E}_{\text {red }}\right.$ of $400 \mathrm{mV}$ for 8 and $457 \mathrm{mV}$ for 12).

To control the performance of organic electronic devices, molecules with energetically low HOMO-LUMO gaps are of primary importance. ${ }^{[22]}$ In this sense, compounds $\mathbf{7 , 8}$ and 12, present a small HOMO-LUMO energy gap $(\sim 0.65-0.94 \mathrm{~V})$, which can be easily tuned by the substituents incorporated in the TCBD unit.

Figure 5 shows the atomic orbital (AO) composition of the highest-occupied (HOMO-1 and HOMO) and lowest-unoccupied (LUMO, LUMO+1 and LUMO+2) molecular orbitals of 8. The HOMO and HOMO-1 are localized on the electron-donor exTTF unit while LUMO and LUMO+1 are basically in TCBD acceptor moiety also extended through anthracene skeleton (specially for LUMO+1). The phenyl group has a small but important contribution in LUMO and LUMO+1. The LUMO+2 is again localized on the exTTF moiety. The atomic orbital composition in compounds $\mathbf{7}$ and $\mathbf{1 2}$ are equivalent to the $\mathbf{8}$ ones. In $\mathbf{7}$ the contribution of the phenyl does not exist and in 12 there is a duplicated LUMO $(\mathrm{L} / \mathrm{L}+1)$ and LUMO+1 $(\mathrm{L}+2 / \mathrm{L}+3)$ due to the extra TCBD group. Attending to the nature of HOMO and LUMO, one can ensure that the first excitations in the three compounds will be charge-transfer (CT) transitions. Moreover it is easy to predict that there will be a higher-energy excitation corresponding to the typical transition $\pi \rightarrow \pi^{*}$ of the exTTF moiety.

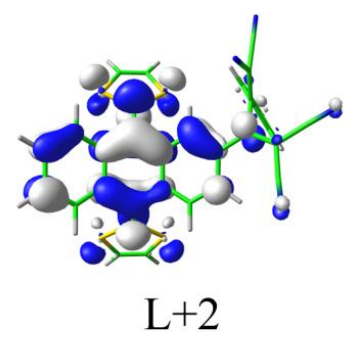

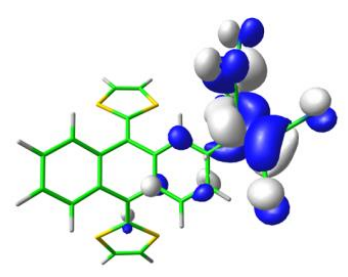

LUMO

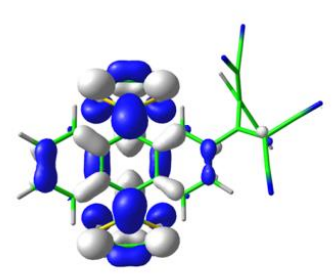

HOMO

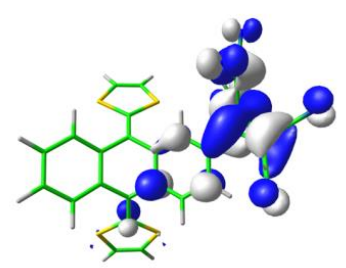

$\mathrm{L}+1$

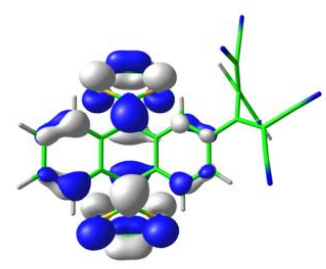

$\mathrm{H}-1$
Figure 5. Electron density contours $\left(0.03 \mathrm{e} \mathrm{bohr}^{-3}\right)$ calculated for the HOMOs and LUMOs of 8 at the B3LYP/6-31G** level. 
Figure 6 shows the energetic diagram of the most relevant molecular orbitals involved in the redox discussion.

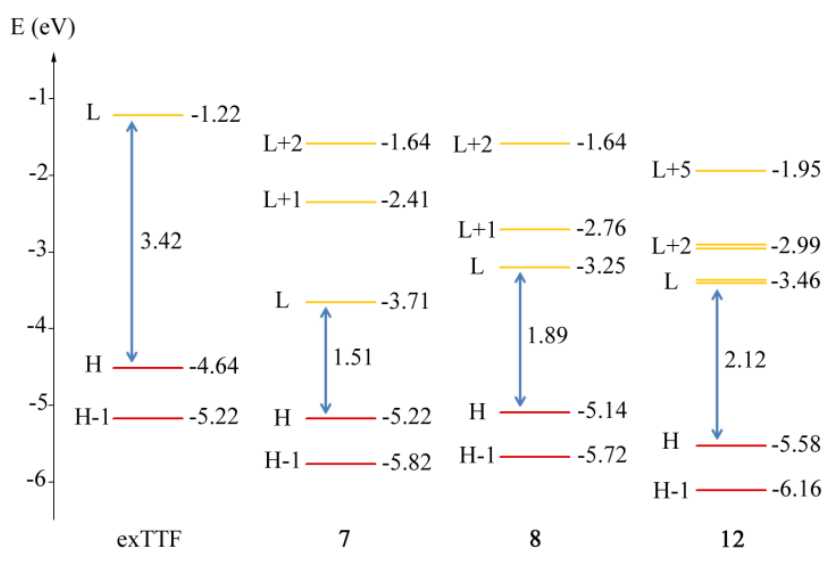

Figure 6. Energy diagram of highest occupied and lowest unoccupied molecular orbitals for exTTF, $\mathbf{7}, \mathbf{8}$ and $\mathbf{1 2}$

Theoretical calculations show that the introduction of the TCBP acceptor group in the exTTF molecule produces a generalized lowering of the energy of exTTF localized orbitals and provoke the appearance of two virtual orbitals in the tetracyanobutadiene part (L and $\mathrm{L}+1$ for $\mathbf{8}$ ). Otherwise the HOMO- 1 and HOMO for $\mathbf{8}$ increase in energy (-5.72 and $-5.14 \mathrm{eV}$, respectively) compared to 7 (-5.82 and 5.22 ) because of the presence of the donor phenyl group in the TCBD moiety. A general decrease in the energy of HOMO-1 and HOMO is observed for 12 (-6.16 and $-5.58 \mathrm{eV}$, respectively) due to the introduction of the second TCBD acceptor unit.

Theoretical calculations considering the PCM model have been also carried out for the dication species in the three derivatives. Results show that the second ionization potentials for compounds 7 , 8 and 12 are 9.97, 10.07 and $10.32 \mathrm{eV}$, respectively, which is in agreement with the oxidation sequence described in the CV. However, if one takes a look to the relative energy of the HOMOs there is a disagreement in the oxidation of the compound $\mathbf{7}$ using Koopmans' theorem: the lower energy of HOMO, the more positive (more difficult) potential to be oxidized. The reason for this apparent discrepancy between experiment and theory is that Koopmans' theorem is a one-electron approach and does not apply to the oxidation process which involves two electrons. An exhaustive study of the conformational structure of the three derivatives shows that 7 can change its trans disposition of the TCBP group to become cis and gain an extra stability (see SI).

In accordance with the electrochemical data, PCM solvent calculations for the first reduced species confirm the experimental trend: the electron affinities obtained for $\mathbf{7}$ and $\mathbf{8}$ are 4.04 and $3.80 \mathrm{eV}$, respectively. A more accurate basis set is also used in order to confirm the results obtained. Now PCM calculations with the $6-31+\mathrm{G}^{* *}$ basis set provide electron affinities of 4.35 and $4.12 \mathrm{eV}$ for $\mathbf{7}$ and $\mathbf{8}$, respectively.

The introduction of the second electron in 7 produces a big distortion in the acceptor unit and therefore a loss of $\pi$-conjugation involving a destabilization. In $\mathbf{8}$ and $\mathbf{1 2}$, that efficient conjugation does not exist because of the twist between the two acceptor halves of TCBD moiety, and there is a phenyl group to accommodate the new electron. Thus, the second reduction is easier to carry out in $\mathbf{8}$ and $\mathbf{1 2}$ rather than in 7 . Furthermore, the reduction processes are strongly influenced by the introduction of substituents ( $\mathrm{Ph}$ vs $\mathrm{H}$ ) not only because of the increase of the molecular distortion from planarity but also for the additional LUMO contribution in the phenyl part which takes an important role in the stabilization of the charge. Because of this, the second peak in the reduction process is positively shifted in $\mathbf{8}$ and $\mathbf{1 2}$ in comparison with 7. A Mulliken charge analysis between 7 and 8 has been performed and it shows that the phenyl group can hold 0.33 electrons from the total 2 introduced.

To control the performance of organic electronic devices, molecules with energetically low HOMO-LUMO gaps are of primary importance. ${ }^{[20]}$ In this sense, compounds $\mathbf{7 , 8}$ and 12, present a small HOMO-LUMO energy gap $(\sim 0.65-0.94 \mathrm{~V})$, which can be easily tuned by the substituents incorporated in the TCBD unit.

Electronic properties. The UV/Vis spectra of the TCBD-exTTF derivatives 7, 8 and $\mathbf{1 2}$ were recorded in diluted dichloromethane solutions (Figure 7) and display the well-know absportions of exTTF in the visible region. ${ }^{[22 b, 23]}$ Additionally, new absoption features are observed in the red part of the spectrum (from $500 \mathrm{~nm}$ ) with absorption onsets recorded in the NIR region (925-1322 nm), which provided HOMO-LUMO gaps between $0.93-1.34 \mathrm{eV}$, in a good linear correlation with the electrochemical gap calculated from the redox potentials of each derivative (see Table 1). Theoretical HOMO-LUMO gaps obtained at B3LYP/6-31G** level (1.51-2.12 eV) follow the same trend of experimental ones.

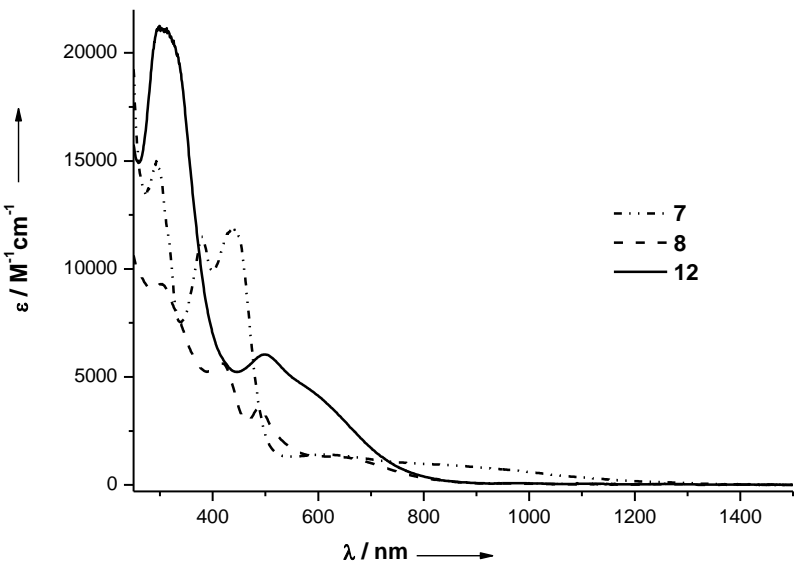

Figure 7. UV/Vis spectra of TCBD-exTTF derivatives 7,8 and 12 in $\mathrm{CH}_{2} \mathrm{Cl}_{2}\left(\mathrm{c}=10^{-5} \mathrm{M}\right)$

These low-energy absorptions correspond to the CT transitions involving the donor exTTF and acceptor TCBD moieties. With quite poor molar extintion coefficients (below $5000 \mathrm{M}^{-1} \mathrm{~cm}^{-1}$ ), these transitions are also weakly solvatochromic withouth a clear trend depending on solvent polarity (see SI for details). Theoretical calculations have been carried out to investigate the nature of the electronic transitions that give rise to the absorption bands observed in the electronic spectra. Time-dependent DFT (TDDFT) has been used with the B3LYP functional. The lowest-energy singlet excited states $\left(S_{\mathrm{n}}\right)$ have been calculated for 7, 8 and 12 at B3LYP/6-31G** level. The results predict that the first two weak bands in all three compounds belong to CT excitations (from the donor unit, exTTF, to the acceptor one, TCBD) whereas the intense bands located about $350-425 \mathrm{~nm}$ are multiconfigurational. Table 2 displays the most 
important excited states that give rise to the lowest-energy bands in $\mathrm{UV} / \mathrm{Vis}$ spectra.

Table 2. Lowest singlet excited states calculated at the TD-DFT-B3LYP level of charge transfer excitations for 7, 8 and 12. Vertical excitation energies (E), energy of experimental bands associated, oscillator strengths (f) and dominant monoexcitations.

\begin{tabular}{cccccc}
\hline & State & $\mathrm{E}(\mathrm{eV})$ & $f$ & Monoexcitations & Exp. band $(\mathrm{eV})$ \\
\hline \multirow{2}{*}{$\mathbf{7}$} & $\mathrm{S}_{1}$ & 1.13 & 0.05 & $\mathrm{H} \rightarrow \mathrm{L}$ & 1.50 \\
& $\mathrm{~S}_{2}$ & 1.70 & 0.03 & $\mathrm{H}-1 \rightarrow \mathrm{L}$ & 2.03 \\
& $\mathrm{~S}_{3}$ & 2.38 & 0.10 & $\mathrm{H} \rightarrow \mathrm{L}+1$ & 2.76 \\
\hline \multirow{4}{*}{$\mathbf{8}$} & $\mathrm{S}_{1}$ & 1.48 & 0.03 & $\mathrm{H} \rightarrow \mathrm{L}$ & 1.91 \\
& $\mathrm{~S}_{2}$ & 1.96 & 0.04 & $\mathrm{H} \rightarrow \mathrm{L}+1$ & 2.48 \\
& $\mathrm{~S}_{3}$ & 2.06 & 0.04 & $\mathrm{H}-1 \rightarrow \mathrm{L}$ & \\
\hline & $\mathrm{S}_{1}$ & 1.71 & 0.02 & $\mathrm{H} \rightarrow \mathrm{L}$ & \multirow{2}{*}{2.07} \\
& $\mathrm{~S}_{2}$ & 1.71 & 0.06 & $\mathrm{H} \rightarrow \mathrm{L}+1$ & \\
$\mathbf{1 2}$ & $\mathrm{S}_{3}$ & 2.17 & 0.02 & $\mathrm{H} \rightarrow \mathrm{L}+3$ & \\
& $\mathrm{~S}_{4}$ & 2.17 & 0.09 & $\mathrm{H} \rightarrow \mathrm{L}+2$ & 2.48 \\
& $\mathrm{~S}_{5}$ & 2.27 & 0.02 & $\mathrm{H}-1 \rightarrow \mathrm{L}+1$ & \\
& $\mathrm{~S}_{6}$ & 2.27 & 0.07 & $\mathrm{H}-1 \rightarrow \mathrm{L}$ & \\
\hline
\end{tabular}

The typical exTTF $\rightarrow$ exTTF band, calculated at $408 \mathrm{~nm}$ for the unsubstituted exTTF, is well predicted by B3LYP at 403 and $389 \mathrm{~nm}$ for compound $\mathbf{8}$ and 12, respectively. However, that transition is not well defined by only one excited state for $\mathbf{7}$, with the most important contributions of excited states $\mathrm{S}_{6}(399 \mathrm{~nm}, f=0.03)$ and $\mathrm{S}_{7}(395 \mathrm{~nm}$, $f=0.12$ ). TD-B3LYP predict too low energy transitions for the CT excitations due to the poor overlaping between molecular orbitals. Since this functional does not make a very good reproduction of the UV/Vis spectra, several calculations with different functionals have been carried out for the first two CT bands of the compound 7 (see SI for more information). The results show that the PBE0 functional is the most suitable approach offering values that differ at most $0.2 \mathrm{eV}$ from the experimental ones and keeping the nature of the transition states. CASSCF/CASPT2 calculations for $\mathbf{7}$ and $\mathbf{8}$ have even been computed in order to confirm the assignment of the bands and corrobore the conformer obtained. A CASPT2 $(4,3)$ calculation for compound 7 gives the first and second CT excited states at 914 and $624 \mathrm{~nm}$, respectively. This result is in very good agreement with the experimental spectra obtained. Moreover, a CASPT2 $(4,4)$ calculation has been performed for molecule $\mathbf{8}$ providing the first three CT transitions at 745, 635 and $592 \mathrm{~nm}$. In addition to this, CASPT2 $(4,3)$ calculations have also been performed for the hypothetic s-trans isomer of compound $\mathbf{7}$ to reject the formation of this species. Results show that the two first CT transitions corresponding to the s-trans isomer are localized at 1279 and $790 \mathrm{~nm}$, which are much lowerenergy than the bands observed for this compound. Finally, to confirm the reability of the results due to the active space employed systematical increments of the active space for $\mathbf{7}$ have been done obtaining no more differences between transition states than $0.1 \mathrm{eV}$.

\section{Conclusions}

We have explored the strategy recently developed by Diederichand co-workers for the preparation of nonplanar push-pull-substituted buta-1,3-dienes, in combination with exTTF units.This methodology, which consists of a $[2+2]$ cycloaddition oftetracyanoethene (TCNE) with electron-donor substitutedalkynes and subsequent cycloreversion, has efficiently provideda new family of highly distorted exTTF-based push-pullchromophores. In addition, we have carried out anexperimental and computational study on their electrochemicaland optical absorption characteristics, which reveals the strongimpact that aryl substitution plays in modulating theoptoelectronic properties of the new chromophores.Based on the
X-ray crystal structure obtained for 12 , we wereable to validate the mechanistic pathway of the reaction, whichconsists of a thermal conrotatory opening of the cyclobutenereaction intermediate that leads to thes-cisconformer. Thelargely twisteds-cis-type conformation adopted by the TCBDunits in the crystal supports this mechanism and corroboratesthe prohibited interconversion of this conformer to the morestables-transowing to the steric hindrance between the donorand acceptor units.Phenyl substitution of the acceptor TCBD units affects boththe oxidation and reduction processes. Oxidation of exTTF is made more difficult both by the conjugation with the strongtetracyanobutadiene acceptor and by the additional stericalhindering induced by the phenyl ring. The reduction processesare strongly influenced by the introduction of phenylsubstituents because they augment the twisting of the TCBDunit and provoke an additional loss of conjugation between thetwo acceptor dicyanovinyl halves of the TCBD unit.Theoretical calculations carried out by using the DFTapproach (B3LYP/6$31 \mathrm{G}^{* *}$ ) forcefully support the exper-imentalfindings. The HOMO and HOMO-1 are localized onthe exTTF moiety, and the introduction of the TCBD unitsdetermines the appearance of lowlying LUMO and LUMO+1orbitals associated to these units. The electronic communica-tion between the electron-donor and electronacceptor frag-ments is supported both by the charge transfer that takes placebetween them for the neutral molecules and by theirparticipation in the reduction and oxidation processes. Thecalculations performed for the dication, anion, and dianionspecies evidence the mutual influence of the donor andacceptor units and explain the experimental trends observed forthe oxidation and reduction potentials. The optical properties of compounds7,8, and12arecharacterized by low- to medium-intense absorption bands thatcompletely cover the visible region and extend to the near-infrared. Theoretical calculations show that these bands are dueto charge-transfer electronic transitions between the donorexTTF moiety and the acceptor TCBD units. The intensity ofthese CT bands is relatively high because, despite the highlydistorted nonplanar structures exhibited by chromophores 7,8 , and 12 , aneffective electronic communication takes placebetween the donor and acceptor units.In summary, the new donor-acceptor chromophores7,8,and12exhibit interesting geometrical and electronic propertieswhich can be tuned by the presence of an aryl group on theTCBD moiety. This strategy paves the way to the synthesis ofmore sophisticated push-pull exTTF derivatives where thesubstituent or functional group present on the starting alkynedetermine the planarity, and hence the electronic properties, ofthefinal chromophore.

\section{Experimental Section}

General methods: All solvents were dried according to standard procedures. Reagents were used as purchased. 2-Iodo-9,10-bis(1,3-dithiol-2-ylidene)-9,10-dihydroanthracene (4), ${ }^{[16]}$ 2-ethynyl-9,10-bis(1,3-dithiol-2-ylidene)-9,10-dihydroanthracene (5) ${ }^{[17]}$ and 2,6diiodo-9,10-bis(1,3-dithiol-2-ylidene)-9,10-dihydroanthracene (9), ${ }^{[17]}$ were prepared using described procedures. All air-sensitive reactions were carried out under argon atmosphere. Flash chromatography was performed using silica gel (Merck, Kieselgel 60, 230-240 mesh or Scharlau 60, 230-240 mesh). Analytical thin layer chromatography (TLC) was performed using aluminum coated Merck Kieselgel 60 F254 plates. NMR spectra were recorded on Bruker Avance 300, 500 or 700 spectrometers at $298 \mathrm{~K}$ using partially deuterated solvents as internal standards. Coupling constants (J) are denoted in $\mathrm{Hz}$ and chemical shifts $(\delta)$ in ppm. Multiplicities are denoted as follows: $\mathrm{s}=$ singlet, $\mathrm{d}=$ doublet, $\mathrm{t}=$ triplet, $\mathrm{m}=$ multiplet, $\mathrm{br}=$ broad. FT-IR spectra were recorded on a Bruker Tensor 27 (ATR device) spectrometer. UV-Vis spectra were recorded on a Varian Cary 
50 spectrophotometer using $\mathrm{CHCl}_{3}$ as solvent. Electrospray Ionization Mass Spectra (ESI-MS) and Matrix Assisted Laser Desorption Ionization (coupled to a Time-Of-Flight analyzer) experiments (MALDI-TOF) were recorded on a HP1100MSD spectrometer and a Bruker REFLEX spectrometer respectively.

Electrochemistry: Electrochemical measurements were performed at room temperature in a potentiostate/galvanostate Autolab PGSTAT30. Measurements were carried out in home-built one-compartment cell with a three-electrode configuration, containing $0.1 \mathrm{M}$ tetrabutylammonium hexafluorophosphate $\left(\mathrm{TBAPF}_{6}\right)$ as supporting electrolyte. A glassy carbon (GCE) was used as the working electrode, a platinum wire as the counter electrode and, a $\mathrm{Ag} / \mathrm{AgNO}_{3}$ non-aqueous electrode was used as reference. Prior to each voltammetric measurement the cell was degassed under an argon atmosphere by $c a .20$ min. The solvent, THF, was freshly distilled from $\mathrm{Na}$. The electrochemical measurement were performed using a concentration of approximately $0.2 \mathrm{mM}$ of the corresponding compound.

2-Phenylethynyl-9,10-bis(1,3-dithiol-2-ylidene)-9,10-dihydroanthracene (6): To a solution of $4(100 \mathrm{mg}, 0.2 \mathrm{mmol})$ in dry THF $(15 \mathrm{~mL})$ under argon atmosphere, were added $\mathrm{Pd}\left(\mathrm{PPh}_{3}\right)_{4}(12 \mathrm{mg}, 0.01 \mathrm{mmol})$ and $\mathrm{CuI}(2 \mathrm{mg}, 0.01 \mathrm{mmol})$, and subsequently phenylacetylene $(0.02 \mathrm{~mL}, 0.2 \mathrm{mmol})$ and triethylamine $(0.13 \mathrm{~mL})$. The mixture was allowed to stir overnight, and then was washed with $\mathrm{NH}_{4} \mathrm{Cl}, \mathrm{H}_{2} \mathrm{O}$ and brine. Afterwards, the solvent was evaporated and the crude product purified by silica gel flash column chromatography (silica gel, hexane:dichloromethane 9:1 to 7:3) to afford product 6 as an orange solid (70\% yield). M.p. $233-235^{\circ} \mathrm{C} .{ }^{1} \mathrm{H} \mathrm{NMR}\left(\mathrm{CDCl}_{3}, 300 \mathrm{MHz}\right): \delta=7.86(\mathrm{~d}, 1 \mathrm{H}$ $J=1.7 \mathrm{~Hz}), 7.71(\mathrm{~m}, 2 \mathrm{H}), 7.57(\mathrm{~m}, 2 \mathrm{H}), 7.46(\mathrm{~m}, 2 \mathrm{H}), 7.36(\mathrm{~m}, 3 \mathrm{H}), 7.31(\mathrm{~m}, 2 \mathrm{H}), 6.33$ (s, $4 \mathrm{H}) \mathrm{ppm} .{ }^{13} \mathrm{C} \mathrm{NMR}\left(\mathrm{CDCl}_{3}, 75 \mathrm{MHz}\right): \delta=135.6,135.5,134.5,134.3,134.2,132.5$, 130.6, 128.1, 127.3, 127.2, 126.9, 125.1, 125.1, 124.9, 124.0, 123.9, 122.4, 120.7, 120.5 $120.3,119.6,116.3,116.2,116.2,88.7,88.6$ ppm. FTIR $(\mathrm{KBr}): v=2923,2854,1716$ 1597, 1546, 1510, 1455, 1407, 1266, 1153, 1094, 1056, 833, 800, 755, $643 \mathrm{~cm}^{-1}$. UV/Vi $\left(\mathrm{CH}_{2} \mathrm{Cl}_{2}\right): \lambda_{\max }(\log \varepsilon)=376$ (4.19), 424 (4.22), 440 (4.26) nm. HRMS (MALDI-TOF) calcd. for $\left[\mathrm{C}_{28} \mathrm{H}_{16} \mathrm{~S}_{4}\right]^{+} 480.0135$; found 479.9987

2,6-Diphenylethynyl-9,10-bis(1,3-dithiol-2-ylidene)-9,10-dihydroanthracene (10): To a solution of $\mathbf{9}(250 \mathrm{mg}, 0.4 \mathrm{mmol})$ in dry THF $(25 \mathrm{~mL})$ under argon atmosphere, were added $\mathrm{Pd}\left(\mathrm{PPh}_{3}\right)_{4}(46 \mathrm{mg}, 0.04 \mathrm{mmol})$ and copper iodide $(8 \mathrm{mg}, 0.04 \mathrm{mmol})$, and subsequently phenylacetylene $(0.13 \mathrm{~mL}, 1.2 \mathrm{mmol})$ and triethylamine $(0.3 \mathrm{~mL})$. The mixture was allowed to stir overnight, and then was washed with $\mathrm{NH}_{4} \mathrm{Cl}, \mathrm{H}_{2} \mathrm{O}$ and brine. Afterwards, the solvent was evaporated and the crude product purified by silica gel flash column chromatography (silica gel, hexane:dichloromethane 9:1 to 7:3) to afford $\mathbf{1 0}$ as an orange solid (65\% yield). ). M.p. $278-282^{\circ} \mathrm{C} .{ }^{1} \mathrm{H} \mathrm{NMR}\left(\mathrm{CDCl}_{3}, 300 \mathrm{MHz}\right): \delta=7.87$ $(\mathrm{d}, 2 \mathrm{H}, J=1.50 \mathrm{~Hz}), 7.69(\mathrm{~d}, 2 \mathrm{H}, J=8.03 \mathrm{~Hz}), 7.56(\mathrm{~m}, 4 \mathrm{H}), 7.46\left(\mathrm{dd}, 2 \mathrm{H}, J_{1}=8.03 \mathrm{~Hz}\right.$ $\left.J_{2}=1.50 \mathrm{~Hz}\right), 7.37(\mathrm{~m}, 6 \mathrm{H}), 6.36,(\mathrm{~s}, 4 \mathrm{H}) \mathrm{ppm} .{ }^{13} \mathrm{C} \mathrm{NMR}\left(\mathrm{CDCl}_{3}, 75 \mathrm{MHz}\right): \delta=136.6$ $134.4,134.2,130.7,128.2,127.3,127.2,126.8,123.9,122.3,119.7,116.4,88.6,88.5$ ppm. FTIR (KBr): v = 2924, 2854, 1737, 1599, 1547, 1499, 1461, 1401, 1263, 1220, 769 $\mathrm{cm}^{-1}$. UV/Vis $\left(\mathrm{CH}_{2} \mathrm{Cl}_{2}\right): \lambda_{\max }(\log \varepsilon)=389$ (4.17), 436 (4.25), 454 (4.31) nm. HRMS (MALDI-TOF): calcd. for $\left[\mathrm{C}_{36} \mathrm{H}_{20} \mathrm{~S}_{4}\right]^{+} 580.8040$; found 580.8020 .

2-(Buta-1,3-diene-1,1,4,4-tetracyano)-9,10-bis(1,3-dithiol-2-ylidene)-9,10-dihydroanthracene (7): A mixture of 5 (100 mg, $0.24 \mathrm{mmol}$ ) and TCNE (31 mg, $0.26 \mathrm{mmol})$ dissolved in 1,2 dichloroethane $(25 \mathrm{~mL})$, was refluxed overnight under argon atmosphere. The solvent was evaporated and the crude was purified by column chromatography on silica gel using dichloromethane as eluent to afford 7 as a dark green solid $(95 \mathrm{mg}, 70 \%$ yield). M.p. $>300^{\circ} \mathrm{C} .{ }^{1} \mathrm{H}$ NMR $\left(\mathrm{CDCl}_{3}, 700 \mathrm{MHz}\right): \delta=8.08$ (s, 1H), $7.94(\mathrm{~d}, 1 \mathrm{H}, J=8.1$ $\mathrm{Hz}), 7.76(\mathrm{~m}, 2 \mathrm{H}), 7.66(\mathrm{~d}, 1 \mathrm{H}, J=1.8 \mathrm{~Hz}), 7.48\left(\mathrm{dd}, 1 \mathrm{H}, J_{1}=8.1 \mathrm{~Hz}, J_{2}=1.8 \mathrm{~Hz}\right), 7.36$ $(\mathrm{d}, 1 \mathrm{H}, J=5.7 \mathrm{~Hz}), 7.35(\mathrm{~d}, 1 \mathrm{H}, J=5.7 \mathrm{~Hz}), 6.41(\mathrm{~m}, 4 \mathrm{H}) \mathrm{ppm} .{ }^{13} \mathrm{C}$ NMR $\left(\mathrm{THF}-\mathrm{d}_{8}, 175\right.$ MHz): $\delta=162.8,155.6,142.4,141.6,140.2,138.1,136.3,136.3,129.8,128.4,127.3$, 127.3, 127.1, 126.8, 126.2, 126.1, 121.6, 121.1, 119.2, 119.1, 119.0, 118.4, 113.6, 113.3 $112.8,110.6,98.3,91.0 \mathrm{ppm}$. FTIR $(\mathrm{KBr}): \mathrm{v}=2961,2923,2853,2225,1594,1543,1501$ $1451,1335,1093,1022,801,756 \mathrm{~cm}^{-1}$. UV/Vis $\left(\mathrm{CH}_{2} \mathrm{Cl}_{2}\right): \lambda_{\max }(\log \varepsilon)=378(4.21), 438$ (4.24), 636 (3.25) nm. HRMS (MALDI-TOF): calcd. for $\left[\mathrm{C}_{28} \mathrm{H}_{12} \mathrm{~N}_{4} \mathrm{~S}_{4}\right]^{+} 531.9939$; found 531.9918 .

2-(3-Phenylbuta-1,3-diene-1,1,4,4-tetracyano)-9,10-bis(1,3-dithiol-2-ylidene)-9,10dihydroanthracene (8): To a solution of $50 \mathrm{mg}(0.1 \mathrm{mmol})$ of 6 in 1,2-dichloroethane $(20 \mathrm{~mL})$ heated to $80^{\circ} \mathrm{C}$, were added $73 \mathrm{mg}(0.56 \mathrm{mmol})$ of TCNE under argon atmosphere. The mixture was allowed to stir for 3 days, and then the solvent was evaporated under reduced pressure and the crude was purified by column chromatography using dichloromethane as eluent, to afford product $\mathbf{8}$ as a dark blue solid (35\% yield) M.p. $>300^{\circ} \mathrm{C} .{ }^{1} \mathrm{H} \mathrm{NMR}\left(\mathrm{CDCl}_{3}, 300 \mathrm{MHz}\right): \delta=8.02\left(\mathrm{dd}, 1 \mathrm{H}, J_{1}=8.5 \mathrm{~Hz}, J_{2}=2.3 \mathrm{~Hz}\right)$ $7.93(\mathrm{~d}, 1 \mathrm{H}, J=8.5 \mathrm{~Hz}), 7.76(\mathrm{~m}, 3 \mathrm{H}), 7.70(\mathrm{~m}, 2 \mathrm{H}), 7.59, \mathrm{~m}, 3 \mathrm{H}), 7.35(\mathrm{~m}, 2 \mathrm{H}), 6.47(\mathrm{~d}$ $2 \mathrm{H}, J=2.1 \mathrm{~Hz}), 6.38(\mathrm{~d}, 1 \mathrm{H}, J=6.5 \mathrm{~Hz}), 6.33(\mathrm{~d}, 1 \mathrm{H}, J=6.5 \mathrm{~Hz}) \mathrm{ppm} .{ }^{13} \mathrm{C} \mathrm{NMR}\left(\mathrm{CDCl}_{3}\right.$, $75 \mathrm{MHz}): \delta=168.1,165.7,143.5,143.2,142.4,139.5,137.4,135.1,135.0,135.0,131.6$ $130.4,130.0,128.8,128.0,127.4,127.1,127.0,126.6,126.5,125.5,125.3,120.9,120.1$, 118.6, 118.3, 118.2, 117.0, 112.6, 112.2, 112.1, 111.6, 88.0, 84.7 ppm. FTIR (KBr): $v=$ $2923,2854,2201,1725,1590,1504,1462,1366,1261,1155,805,725,554 \mathrm{~cm}^{-1}$. UV/Vis $\left(\mathrm{CH}_{2} \mathrm{Cl}_{2}\right): \lambda_{\max }(\log \varepsilon)=421$ (3.75), 491 (3.56), 656 (3.12) nm. HRMS (MALDI-TOF) calcd. for $\left[\mathrm{C}_{28} \mathrm{H}_{12} \mathrm{~N}_{4} \mathrm{~S}_{4}\right]^{+}$531.9939; found 531.9918 .

Doubly TCBD functionalization general method. $100 \mathrm{mg}(0.17 \mathrm{mmmol})$ of $\mathbf{1 0}$ were dissolved in $30 \mathrm{~mL}$ of 1,2-dichloroethane and the solution was heated to $80^{\circ} \mathrm{C} .240 \mathrm{mg}$ $(1.9 \mathrm{mmol})$ of TCNE were then added, and the reaction was allowed to stir for 5 days.
Then, the solvent was removed under vacuum and the crude products were separated and purified by column chromatography (silica gel, dichloromethane)

\section{2-(3-Phenylbuta-1,3-diene-1,1,4,4-tetracyano)-6-(phenylethynyl)-9,10-bis(1,3} dithiol-2-ylidene)-9,10-dihydroanthracene (11): $9 \mathrm{mg}$ of a dark blue solid (8\% yield) M.p. > $300^{\circ} \mathrm{C} .{ }^{1} \mathrm{H} \mathrm{NMR}\left(\mathrm{CDCl}_{3}, 300 \mathrm{MHz}\right): \delta=8.02\left(\mathrm{dd}, 1 \mathrm{H}, J_{l}=8.7 \mathrm{~Hz}, J_{2}=2.1 \mathrm{~Hz}\right)$ $7.94(\mathrm{~d}, 1 \mathrm{H}, J=8.7 \mathrm{~Hz}), 7.91(\mathrm{~d}, 1 \mathrm{H}, J=1.3 \mathrm{~Hz}), 7.77\left(\mathrm{dd}, 2 \mathrm{H}, J_{l}=8.2 \mathrm{~Hz}, J_{2}=1.5 \mathrm{~Hz}\right)$, $7.71(\mathrm{~d}, 1 \mathrm{H}, J=7.5 \mathrm{~Hz}), 7.68(\mathrm{~d}, 1 \mathrm{H}, J=7.5 \mathrm{~Hz}) .7 .59(\mathrm{~m}, 4 \mathrm{H}), 7.50\left(\mathrm{dd}, 1 \mathrm{H}, J_{l}=8.0\right.$ $\left.\mathrm{Hz}, J_{2}=1.5 \mathrm{~Hz}\right), 7.39(\mathrm{~m}, 4 \mathrm{H}), 6.50(\mathrm{~s}, 2 \mathrm{H}), 6.42(\mathrm{~d}, 1 \mathrm{H}, J=6.7 \mathrm{~Hz}), 6.36(\mathrm{~d}, 1 \mathrm{H}, J=6.7$ $\mathrm{Hz}) \mathrm{ppm} .{ }^{13} \mathrm{C} \mathrm{NMR}\left(\mathrm{CDCl}_{3}, 75 \mathrm{MHz}\right): \delta=168.0,165.6,144.2,142.2,140.5,137.3,135.2$, $135.1,134.9,132.2,132.1,132.0,131.6,130.5,130.1,129.9,128.9,128.9,128.8,128.8$ $128.1,128.1,127.5,126.6,126.5,125.5,123.5,121.8,120.0,119.6,118.7,118.5,118.3$, $117.2,112.6,112.2,112.1,111.6,90.6,89.7,88.0,84.8$ ppm. FTIR $(\mathrm{KBr}): v=2955$ $2910,2840,2190,1670,1650,1500,1383,1375,1340,1180,990,965,606 \mathrm{~cm}^{-1}$. UV/Vis $\left(\mathrm{CH}_{2} \mathrm{Cl}_{2}\right): \lambda_{\max }(\log \varepsilon)=805(2.28), 439$ (3.23), 368 (3.77), 305 (3.68) nm. HRMS (MALDI-TOF): calcd. for $\left[\mathrm{C}_{42} \mathrm{H}_{20} \mathrm{~N}_{4} \mathrm{~S}_{4}\right]^{+} 708.0571$; found 707.9915 .

2,6-Di-(3-phenylbuta-1,3-diene-1,1,4,4-tetracyano)-9,10-bis(1,3-dithiol-2-ylidene)9,10-dihydroanthracene (12): $45 \mathrm{mg}$ of a dark-blue solid (35\% yield). M.p. $>300^{\circ} \mathrm{C}$ ${ }^{1} \mathrm{H}$ NMR $\left(\mathrm{CDCl}_{3}, 500 \mathrm{MHz}\right): \delta=7.95(\mathrm{~m}, 4 \mathrm{H}), 7.84(\mathrm{~d}, 2 \mathrm{H}, J=1.9 \mathrm{~Hz}), 7.77(\mathrm{~m}, 4 \mathrm{H})$, $7.70(\mathrm{~m}, 2 \mathrm{H}), 7.61(\mathrm{~m}, 4 \mathrm{H}), 6.54(\mathrm{~d}, 2 \mathrm{H}, J=6.8 \mathrm{~Hz}), 6.48(\mathrm{~d}, 2 \mathrm{H}, J=6.8 \mathrm{~Hz}) \mathrm{ppm} .{ }^{13} \mathrm{C}$ NMR $\left(\mathrm{CDCl}_{3}, 125 \mathrm{MHz}\right): \delta=167.9,165.5,146.2,141.6,136.8,135.3,131.5,130.6$, 129.9, 128.7, 127.9, 126.7, 126.3, 119.1, 118.4, 118.2, 112.4, 112.1, 111.9, 111.6, 88.0, 85.7 ppm. FTIR (KBr): $v=2958,2922,2854,2208,1735,1505,1383,1261,1212,1185$, 1099, 1026, 805, $534 \mathrm{~cm}^{-1}$. UV/Vis $\left(\mathrm{CH}_{2} \mathrm{Cl}_{2}\right): \lambda_{\max }(\log \varepsilon)=502(3.79), 606(3.62) \mathrm{nm}$. HRMS (MALDI-TOF): calcd. for $\left[\mathrm{C}_{48} \mathrm{H}_{20} \mathrm{~N}_{8} \mathrm{~S}_{4}\right]^{+}$836.0694; found 836.0652.

\section{Acknowledgements}

Financial support by the MICINN of Spain (CTQ2011-24652, PIB2010JP-00196, and 2010C-07-25200), FUNMOLS (FP7-212942-1), and the CAM (MADRISOLAR-2 S2009/PPQ-1533) is acknowledged. R.G. and J. L. D. thank the MICINN for a FPU studentship and a Ramón y Cajal fellowship cofinanced by the European Social Fund, respectively.

[1] a) A. Pron, P. Gawrys, M. Zagorska, D. Djurado, R. Demadrille, Chem. Soc. Rev. 2010, 39, 2577-2632, b) C. Koos, P. Vorreau, T. Vallaitis, P. Dumon, W. Bogaerts, R. Baets, B. Esembeson, I. Biaggio, T. Michinobu, F. Diederich, W. Freude, J. Leuthold, Nat. Photonics 2009, 3, 216-219, c) S. Sumalekshmy, M. M. Henary, N. Siegel, P. V. Lawson, Y. Wu, K. Schmidt, J.-L. Brédas, J. W. Perry, C. J. Fahrni, J. Am. Chem. Soc. 2007, 129, 11888-11889.

[2] a) Special issue on Organic Photovoltaics, Acc. Chem. Res. 2009, 42, 1689-1857, b) M. K. R. Fischer, S. Wenger, M. Wang, A. Mishra, S. M. Zakeeruddin, M. Grätzel, P. Bäuerle, Chem. Mater. 2010, 22, 1836-1845, c) E. L. Unger, E. Ripaud, P. Leriche, A. Cravino, J. Roncali, E. M. J. Johansson, A. Hagfeldt, G. Boschloo, J. Phys. Chem. C 2010, 114, 11659-11664, d) J. L. Delgado, P.-A. Bouit, S. Filippone, M. A. Herranz, N. Martín, Chem. Commun. 2010, 46, 4853-4865.

[3] a) B. Walker, A. B. Tamayo, X.-D. Dang, P. Zalar, J. H. Seo, A. Garcia, M Tantiwiwat, T.-Q. Nguyen, Adv. Funct. Mater. 2009, 19, 3063-3069, b) U. Mayerhöffer, K. Deing, K. Gruß, H. Braunschweig, K. Meerholz, F. Würthner, Angew. Chem. 2009, 121, 8934-8937; Angew. Chem. Int. Ed. 2009, 48, 8776-8779, c) X. Zhao, C. Piliego, B. Kim, D. A. Poulsen, B. Ma, D. A. Unruh, J. M. J. Fréchet, Chem. Mater. 2010, 22, 2325-2332, d) R. Fitzner, E. Reinold, A. Mishra, E. Mena-Osteritz, H. Ziehlke, C. Körner, K. Leo, M. Riede, M. Weil, O. Tsaryova, A. Weiß, C. Uhrich, M. Pfeiffer, P. Bäuerle, Adv. Funct. Mater. 2011, 21, $897-$ 910, e) J. Zhang, G. Wu, C. He, D. Deng, Y. Li, J. Mater. Chem. 2011, 21, 3768 3774 ,

[4] a) J. Roncali, P. Leriche, A. Cravino, Adv. Funct. Mater. 2007, 19, 2045-2060, b T. M. Pappenfus, D. K. Schneiderman, J. Casado, J. T. López Navarrete, M. C. Ruiz Delgado, G. Zotti, B. Vercelli, M. D. Lovander, L. M. Hinkle, J. N. Bohnsack, K. R. Mann, Chem. Mater. 2011, 23, 823-831.

[5] a) S.-I. Kato, F. Diederich, Chem. Commun. 2010, 46, 1994-2006, b) M. Yamada, P. Rivera-Fuentes, W. B. Schweizer, F. Diederich, Angew. Chem. 2010, 122, 3611-3615; Angew. Chem. Int. Ed. 2010, 49, 3532-3535, c) M. Jordan, M. Kivala, C. Boudon, J.-P. Gisselbrecht, W. B. Schweizer, P. Seiler, F. Diederich, Chem. Asian J. 2011, 6, 396-401, d) B. Breiten, Y.-L. Wu, P. D. Jarowski, J.-P. Gisselbrecht, C. Boudon, M. Griesser, C. Onitsch, G. Gescheidt, W. B. Schweizer, N. Langer, C. Lennartz, F. Diederich, Chem. Sci. 2011, 2, 88-93.

[6] S.-I. Kato, M. Kivala, W. B. Schweizer, C. Boudon, J.-P. Gisselbrecht, F. Diederich, Chem. Eur. J. 2009, 15, 8687-8691.

[7] P. Fesser, C. Iacovita, C. Wckerlin, S. Vijayaraghavan, N. Ballav, K. Howes, J.P. Gisselbrecht, M. Crobu, C. Boudon, M. Stöhr, T. A. Jung, F. Diederich, Chem. Eur. J. 2011, 17, 5246-5250.

[8] K. Walzer, B. Maennig, M. Pfeiffer, K. Leo, Chem. Rev. 2007, 107, 1233-1271. 
[9] a) M. Bendikov, F. Wudl, D. F. Perepichka, Chem. Rev. 2004, 104, 4891-4946, b) N. Martín, L. Sánchez, M. A. Herranz, B. Illescas, D. M. Guldi, Acc. Chem Res. 2007, 40, 1015-1024, c) F. G. Brunetti, J. L. López, C. Atienza, N. Martín " J. Mater. Chem. 2012, 22, 4188-4205, d) Y. Takano, M. A. Herranz, N. Martín, S. Gayathri Radhakrishnan, D. M. Guldi, T. Tsuchiya, S. Nagase, T. Akasaka, $J$ Am. Chem. Soc. 2010, 132, 8048-8055, e) J. Santos, B. M. Illescas, N. Martín, J. Adrio, J. C. Carretero, R. Viruela, E. Ortí, F. Spänig, D. M. Guldi, Chem. Eur. J. 2011, 17, 2957-2964.

[10] a) D. M. Guldi, B. M. Illescas, C. M. Atienza, M. Wielopolski, N. Martín, Chem.Soc. Rev. 2009, 38, 1587-1597, b) A. Molina-Ontoria, M. Wielopolski, J. Gebhardt, A. Gouloumis, T. Clark, D. M. Guldi, N. Martín, J. Am. Chem. Soc. 2011, 133, 2370-2373, c) M. Wielopolski, J. Santos, B. M. Illescas, A. Ortiz, B. Insuasty, T. Bauer, T. Clark, D. M. Guldi, N. Martín, Energy Environ. Sci. 2011, 4, 765-771.

[11] M. Otero, M. A. Herranz, C. Seoane, N. Martín, J. Garín, J. Orduna, R. Alcalá, B. Villacampa, Tetrahedron 2002, 58, 7463-7475.

[12] a) E. M. Pérez, N. Martín, Chem. Soc. Rev. 2008, 37, 1512-1519, b) E. Huerta, H Isla, E. M. Pérez, C. Bo, N. Martín, J. de Mendoza, J. Am. Chem. Soc. 2010, 132, 5351-5353, c) H. Isla, M. Gallego, E. M. Pérez, R. Viruela, E. Ortí, N. Martín, J. Am. Chem. Soc. 2010, 132, 1772-1773, d) B. Grimm, J. Santos, B. M. Illescas, A Muñoz, D. M. Guldi, N. Martín. J. Am. Chem. Soc. 2010, 132, 17387-17389, e) D. Canevet, M. Gallego, H. Isla, A. de Juan, E. M. Pérez, N. Martín, J. Am.Chem. Soc. 2011, 133, 3184-3190

[13] S. Wenger, P.-A. Bouit, Q. Chen, J. Teuscher, D. Di Censo, R. Humphry-Baker, J.-E. Moser, J. L. Delgado, N. Martín, S. M. Zakeeruddin, M. Grätzel, J. Am. Chem. Soc. 2010, 132, 5164-5169.

[14] R. Andreu, E. Galán, J. Orduna, B. Villacampa, R. Alicante, J. T. López Navarrete, J. Casado, J. Garín, Chem. Eur. J. 2011, 17, 826-838.

[15] a) D. F. Perepichka, M. R. Bryce, I. F. Perepichka, S. B. Lyubchik, C. A Christensen, N. Godbert, A. S. Batsanov, E. Levillain, E. J. L. McInnes, J. P. Zhao, J. Am. Chem. Soc. 2002, 124, 14227-14238, b) C. A. Christensen, A. S. Batsanov, M. R. Bryce, J. Am. Chem. Soc. 2006, 128, 10484-10490.
[16] M. C. Díaz, B. M. Illescas, C. Seoane, N. Martín, J. Org. Chem. 2004, 69, 44924499 .

[17] B. M. Illescas, J. Santos, M. C. Díaz, N. Martín, C. M. Atienza, D. M. Guldi, Eur J. Org. Chem. 2007, 5027-5037.

[18] For an exhaustive investigation about consecutive [2+2] cycloadditioncycloreversion reactions in activated internal acetylenes, please see: F. Silvestri, M. Jordan, K. Howes, M. Kivala, P. Rivera-Fuentes, C. Boudon, J.-P. Gisselbrecht, W. B. Schweizer, P. Seiler, M. Chiu, F. Diederich, Chem. Eur. J. 2011, 17, 6088-6097.

[19] a) M. R. Bryce, A. J. Moore, M. Hasan, G. J. Ashwell, A. T. Fraser, W. Clegg, M. B. Hursthouse, A. I. Karaulov, Angew. Chem. 1990, 102, 1493-1495; Angew. Chem. Int. Ed. Engl. 1990, 29, 1450-1452, b) A. E. Jones, C. A. Christensen, D. F. Perepichka, A. S. Batsanov, A. Beeby, P. J. Low, M. R. Bryce, A. W. Parker, Chem. Eur. J. 2001, 7, 973-978, c) C. A. Christensen, A. S. Batsanov, M. R. Bryce, J. A. K. Howard, J. Org. Chem. 2001, 66, 3313-3320.

[20] a) N. Martín, L. Sánchez, C. Seoane, E. Ortí, P. M. Viruela and R. Viruela, J. Org. Chem. 1998, 63, 1268-1279, b) M. C. Díaz, B. M. Illescas, N. Martín, R. Viruela, P. M. Viruela, E. Ortí, O. Brede, I. Zilbermann and D. M. Guldi, Chem. Eur. J. 2004, 10, 2067-2077, c) P.-A. Bouit, C. Villegas, J. L. Delgado, P. M. Viruela, R. Pou-Amérigo, E. Ortí and N. Martín, Org. Lett. 2011, 13, 604-607.

[21] a) I. Pérez, S.-G. Liu, N. Martín, L. Echegoyen, J. Org. Chem. 2000, 65, 37963803. b) M. A. Herranz, L. Yu, N. Martín, L. Echegoyen, J. Org. Chem. 2003, 68 , 8379-8385.

[22] N. Gautier, F. Dumur, V. Lloveras, J. Vidal-Gancedo, J. Veciana, C. Rovira, P. Hudhomme, Angew. Chem. 2003, 115, 2871-2874; Angew. Chem. Int. Ed. 2003, 42, 2765-2768

[23] D. M. Guldi, L. Sánchez, N. Martín, J. Phys. Chem. B 2001, 105, 7139-7144. 
